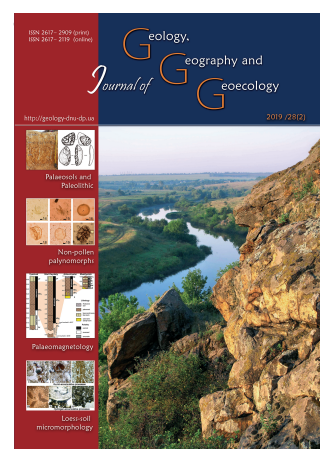

Journal of Geology.

ISSN 2617-2909 (print)

ISSN 2617-2119 (online)

Geography and

Geoecology

Journ.Geol.Geograph.

Geology,

28(2), 348-354.

Journal home page: geology-dnu-dp.ua

doi: $10.15421 / 111933$

Rohozin Ye.

Journ. Geol. Geograph. Geoecology, 28(2), 348-354.

\title{
Non-pollen palynomorphs as indicators of palaeoenvironmental changes: a case study from Lake Chokrak (the Crimean Peninsula)
}

\author{
Ye. P. Rohozin
}

Taras Shevchenko National University of Kyiv, Kyiv,Ukraine, e-mail: yevhenii.rohozin@knu.ua

Received: 15.04 .2019

Received in revised form: 18.05 .2019

Accepted: 21.05.2019
Abstract. The paper presents the first study of the non-pollen palynomorphs assemblages of the upper Holocene sediments of hypersaline Lake Chokrak. As has been previously shown, the Crimean saline lakes tend to have low variety and frequencies of non-pollen palynomorphs (Mudie et al., 2011). The upper samples from Lake Chokrak have yielded high pollen frequencies, as well as a relatively diverse assemblage of NPPs, including acritarchs, dinoflagellate cysts, microforaminiferal linings, fungal spores, eggs of Artemia salina, ostracod jaws and arthropod parts. Acritarchs are represented mostly by Sigmopollis sp., which are abundant in all the studied samples, and by occasional Micrhystridium sp. and Pseudoschizaea circula. Among the fungal spores, Podospora, Delitschia and Sporormiella have been identified, indicating a former settlement. Three species of dinoflagellate cysts have been identified, Lingulodinium machaerophorum, Impagidinium caspiense and Spiniferites cf. crusiformis. These species are found in brackish/marine environments and do not tolerate high water salinity. They could have been transported to the lake by overflowing marine waters over the sand barrier between the lake and the Sea of Azov. Therefore, their appearance in the lake sediments may indicate possible sea-level changes and/or increased wave activity. So far, within the analysed top $2 \mathrm{~m}$ of the core, we can distinguish five intervals where dinocysts and microforaminiferal linings are present, possibly indicating increased marine influence, separated by four intervals where few or no brackish species have been found. Impagidinium caspiense is a dominant species among the dinocysts in all the samples, except the surface sample, where L. machaerophorum is much more abundant. This could indicate the increased salinity and/or higher nutrient loading to the Sea of Azov during the XX century. The allochthonous nature of dinocysts and some other NPPs in the Lake Chokrak sediments can play an important role in reconstructing level changes of the Sea of Azov and depositional environment of the lake, as well as contribute to the interpretation of pollen data.

Key words: non-pollen palynomorphs, lake sediments, Black Sea, Holocene.

\section{Непилкові паліноморфи як індикатори палеогеографічних змін на прикладі озера Чо- крак (Кримський півострів)}

\section{Є. П. Рогозін}

Київський національний університет імені Тараса Шевченка,Київ Україна, е-таil: уеvhепіi.rohozin@,knи.иа

Анотація. У статті вперше представлено дослідження непилкових паліноморф у верхньоголоценових відкладах гіперсолоного озера Чокрак. Як було показано раніше, соляні озера Криму мають низький рівень різноманіття та концентрації непилкових паліноморф (Mudie et al., 2011). Досліджені зразки відкладів мають високу концентрацію пилку, та відносно різноманітний спектр НПП, включаючи акрітархи, цисти динофлагелят, оболонки мікрофорамініфер, спори грибів, яйця Artemia salina, щелепи остракодів та частини скелету Cladocera. Акрітархи представлено переважно Sigmopollis sp., які переважають в усіх досліджених зразках, та поодинокими спорами Micrhystridium sp. та Pseudoschizaea circula. Серед спор грибів було виявлено спори Podospora, Delitschia та Sporormiella, які є іникаторами давнього поселення. Ідентифіковано три види цист динофлагелят - Lingulodinium machaerophorum, Impagidinium caspiense i Spiniferites cf. crusiformis. Ці види надають перевагу солонуватим та морським водам і не переносять надто високу солоність води. Вони могли бути принесеними в озеро морськими водами, які переливалися через пересип між озером та Азовським морем. Таким чином, наявність цих паліноморф $\epsilon$ індикатором, як імовірних змін рівня моря, так і збільшення припливних хвиль. У проаналізованих відкладах, потужністю 2 м, виявлено п’ять інтервалів, у яких присутні цисти динофлагелят та оболонки мікрофорамініфер, які представляють збільшення впливу моря на узбережжя, які чергуються з чотирма інтервалами, у яких не виявлено видів, які проживають у солонуватих водах. Цисти Impagidinium caspiense переважають у всіх зразках, окрім поверхневого, у якому L. machaerophorum представлено у більших кількостях. Це може вказувати на підвищення солоності та збільшення надходження поживних речовин у Азовське море 
протягом XX ст. Алохтонне походження диноцист та інших НПП у відкладах озера Чокрак може відігравати важливу роль як у реконструкції змін рівня Азовського моря та басейну осадконакопичення озера, так і доповнювати спорово-пилкові дані.

Ключові слова: непилкові паліноморфи, озерні відклади, Чорне море, голочен.

Introduction. Environmental changes that have been occurring in the Black Sea region through the Holocene are associated with climatic changes and fluctuations of the Black Sea basin. These short-term changes can be reconstructed using continuous sedimentary archives, like the saline lakes in the Crimean Peninsula. Many of these lakes have annually laminated sediments, the fact that enables high-resolution palaeoenvironmental reconstructions of the lake and its surroundings. Palynological content of these lacustrine sediments is of particular use for reconstructions of past vegetation cover and land-use practices, and modelling of climate changes. Pollen and spore content of various sediment types have long been studied by Quaternary researches, but there have been comparatively few studies of non-pollen palynomorphs in the marine and lacustrine sediments in the Black Sea and the adjacent area. Non-pollen palynomorphs (NPPs) are other microfossils than pollen and spores from vascular plants observed in palynological samples. Their usage as palaeoecological indicators is rapidly growing because of their potential to reconstruct palaeohydrological regime and to complement reconstructions of past vegetation cover based on pollen analysis.

The history of non-pollen palynomorphs studies in the Black Sea region starts with works by Wall et al. (1973) and Wall and Dale (1974), who first described new types of dinoflagellates in the brackish waters of the Black Sea and outlined their affinities to water salinity. Traverse (1974) described two dinocyst species and three acritarchs in the south-eastern part of the Black Sea. Later, Traverse (1978) presented and illustrated some NPPs in the Black Sea cores, including fungal spores, several types of dinocysts, Botryococcus, Pediastrum, and several types of acritarchs ( $C y$ matiospherae, Tasmanites, Pseudoschizaea). Mudie et al. (2002) described the abundance of dinocysts species, acritarchs, fungal spores and microforaminiferal linings in the Marmara and Black Seas in the Upper Pleistocene-Holocene sediments and the influence of salinity on their distribution patterns. Marret et al. (2009) proposed a two-step transformation of the Black Sea basin in the early Holocene using brackish and euryhaline assemblages of dinocysts. More recently, Mudie et al. (2011) illustrated different types of NPPs in the Caspian-Black Sea-Mediterranean corridor, their frequencies in marine, estuarine and lacustrine sediments, and their value as indicators of salinity and nutrient level of waters and human activity in the region. Shumilovskikh et al. (2013) reconstructed sea-surface salinities and temperatures of the southeastern part of the Black Sea during the Holocene and Eemian using freshwater/brackish and marine assemblages of dinocysts. Zonneveld et al. (2013) mapped and described present-day environmental conditions and geographic distribution of dinocysts in sediments based on 2405 data points, including several points in the Black Sea. To summarise research results over the past decades, Mudie et al. (2017) presented atlas of modern dinocysts distribution in the Black Sea corridor (based on 185 surface samples), in which relationships between the distribution of individual dinocyst species are described, as well as such water parameters as salinity, temperature, nutrient content and bottom water oxygen. The first standardised taxonomy of the dinoflagellate cysts found in the Black Sea corridor was provided. As can be seen, the NPP studies in the Black Sea have been rapidly developing, producing new important data on geographic distribution and ecological affinities of individual species of NPPs.

In this paper, we analysed NPP content from the upper Holocene sediments of hypersaline Lake Chokrak, in the north-east of the Crimean Peninsula. The specific objectives are 1) characterisation of diversity and concentration of NPP in the sediment samples, 2) investigation of mechanisms of their distribution in the lake, and 3) outlining indicative environmental value of individual species.

Materials and methods. Lake Chokrak is a hypersaline coastal lake in the north-east of the Crimean Peninsula (Fig. 1). The lake is a former marine lagoon, which evolved around 5,000 years BP due to postglacial transgression of the Black Sea (Kurnakov et al., 1932). Marine conditions terminated around 4,000-3,000 BP, when a sand barrier started to form and separated the lake from the Sea of Azov (Kelterbaum et al., 2012). At present, the lake is separated by a sand barrier up to $350 \mathrm{~m}$ in width. The area of the lake is $8.5 \mathrm{~km}^{2}$ and the maximum depth is $1.3 \mathrm{~m}$. The sediments of the lake show annual lamination: it is suggested that dark spring layers of washed off soil are coupled with light summer evaporite layers. The climate of the study area is arid and continental. The present mean annual temperature is $11^{\circ} \mathrm{C}$, with mean July temperatures of $24^{\circ} \mathrm{C}$, and mean January temperatures of $-1^{\circ} \mathrm{C}$. Annual amount of precipitation does not exceed $350 \mathrm{~mm}$. At present, Lake Chokrak dries up completely during summer (July-August). The sa- 


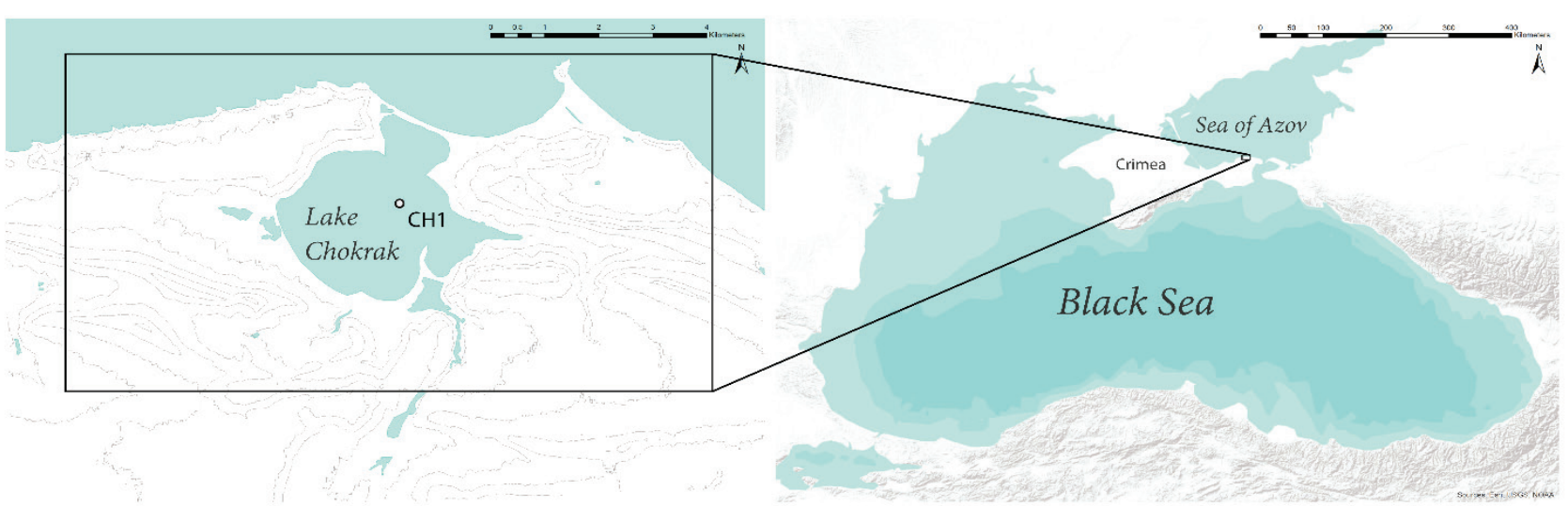

Fig. 1. Left: a map of the study area around Lake Chokrak showing the location of core CH1. Right: a map of the Black Sea region showing the location of Lake Chokrak.

linity of the lake ranges from 80 to $180 \%$, whereas the Sea of Azov near the study site has the salinity of $11.5 \%$. The bedrock consists of Neogene clays, limestones and marls, which are frequently exposed around the lake. The soil cover is composed of chernozems on heavy clays. The vegetation cover of the study area is represented by grassland with admixture of Artemisia and Chenopodiaceae, and the lake itself is surrounded by halophytic vegetation.

The 11-metre core $\mathrm{CH}-1$ was collected from the western part of Lake Chokrak $\left(45^{\circ} 27^{\prime} 37^{\prime \prime} \mathrm{N}\right.$, $\left.36^{\circ} 18^{\prime} 10^{\prime \prime} \mathrm{E}\right)$ within the framework of USA-Ukraini- rope" (1995-1999). The core was subsampled at 5-cm interval with the aim to reveal sort-term palaeoenvironmental changes of the lake and its vicinities. The laboratory processing of the subsamples involved treatment with $10 \% \mathrm{HCl}$ in a hot water bath, hot treatment with $10 \% \mathrm{NaOH}$, cold treatment with $40 \% \mathrm{HF}$ and secondary treatment with $10 \% \mathrm{HCl}$ to remove the secondary formed salts and calcium. The residues were mounted in glycerol and analysed under a light microscope. Mudie et al. (2011) notes that the use of acetolysis or hot $10 \% \mathrm{KOH}$ may decrease the number of recovered palynomorphs as some dinoflagellate

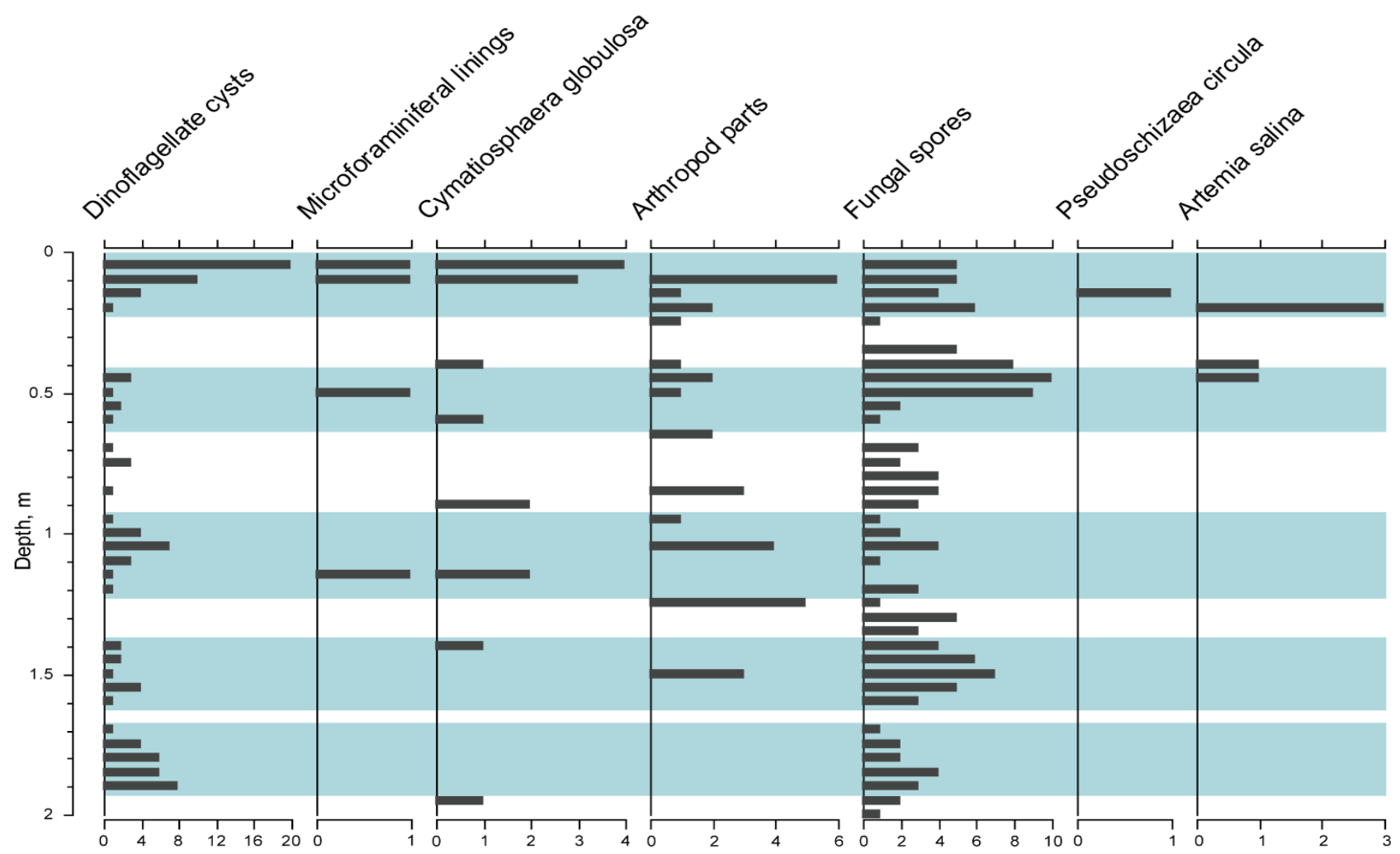

Fig. 2. Diagram of main NPP groups in the Lake Chokrak samples. The taxa are shown in numbers of specimens. Blue zones indicate intervals of increased marine influence on the lake basin.

an-Russian project "High resolution Holocene proxy precipitation record in varved lake beds of Eastern $\mathrm{Eu}$ - cysts are extremely sensitive to oxidation. The identification of dinoflagellate cysts was preformed using 
modern atlases and keys (e.g. van Geel, 2001; Mudie et al., 2011, 2017; Zonneveld, Pospelova, 2015).

Results. The upper sediment samples from Lake Chokrak have yielded high pollen frequencies, as well as a relatively diverse assemblage of NPPs, including dinoflagellate cysts, prasinophytes and acritarchs, fungal spores, foraminiferal linings and other animal remains (Fig. 2, 3). No specimens of Chlorococcales, like Pediastrum or Botryococcus, Zygnematales or cyanobacteria have been recorded in the samples.

Dinoflagellate cysts. Dinocyst content in the Lake Chokrak samples is not abundant. Their values range from being virtually absent to about $3 \%$ of the total pollen sum. The highest number of dinocysts ( 20 specimens) is recorded in the topmost sample, and in the lower samples, 10 or fewer specimens were observed. Dinocyst occurrence in the Lake Chokrak samples follows a certain pattern, being absent or present across several samples in line. The following species have been identified: Lingulodinium machaerophorum, Gonyaulax baltica (the motile stage of Impagidinium caspiense), Impagidinium caspiense, Spiniferites cf. cruciformis. Lingulodinium machaerophorum and Impagidinium caspiense are most abundant in the samples, and the others are rarely observed.

Prasinophytes and acritarchs. Prasinophytes are represented by Cymatiosphaera globulosa, which appears sporadically in the samples and does not exceed $0.8 \%$ of the total pollen sum. Most specimens are recorded in the upper part of the sequence. Acritarchs are most abundant palynomorphs in all studied samples, especially Sigmopollis-type, and occasionally Micrhystridium and Pseudoschizaea circula were observed.

Fungal spores. Fungal spores are encountered in almost all samples, but they are more diverse in the top part of the sequence $(0.0-1.0 \mathrm{~m})$. Their content ranges between $1.0 \%$ and $2.5 \%$ of the pollen sum. From the total fungal spore assemblage, we have been able to identify Glomus-type, Podospora spp., Delitschia sp. and Sporormiella sp.

Animal remains. In the samples, several specimens of trochospiral organic linings of microforaminifera were recorded. Ostracod mandibles are occasionally observed in the upper part of the sequence (0.0-1.75 m), along with exoskeletal parts of juvenile Cladocera and eggs of Artemia salina.

Interpretation. Dinoflagellates are the organic-walled encysted stages of the life cycle of this group of onecelled organisms. Most dinoflagellates are of marine origin, although freshwater specimens are known. Due to high salinity of Lake Chokrak, dinocysts do not make up a large part of the fossil assemblage as they would do in marine sediments. Nonetheless, they are common in the upper part of the sequence to represent marine influence on the lake. Mudie et al. (2011) reported that organic-walled dinocysts had not been found in the saline Crimean lakes Saki and Dzharylgach, probably because of alkaline environment of the lakes or laboratory treatment with $\mathrm{KOH}$. Lingulodinium machaerophorum is the most widespread and often the most abundant species of the Black Sea corridor (Mudie et al., 2010). The species is present in many types of waters, although not found in low salinity basins. The specimens are generally found in coastal areas and regions in the vicinity of continental margins, where sea-surface temperate is above $10^{\circ} \mathrm{C}$ and salinity ranges between 8.5 and 39.4\%o (Mudie et al., 2017). High relative abundances of Lingulodinium machaerophorum occur both in high and low sea surface salinities (the latter is as a result of river discharge). They are abundant in regions with strong (seasonal) variability in the trophic state of the upper waters (Zonneveld et al., 2013). In the Lake Chokrak sediments, Lingulodinium machaerophorum is most abundant in the top sample $(0.05 \mathrm{~m})$, and being an euryhaline species, it is more indicative of nutrient loading to the Sea of Azov than of changes in the seasurface salinity.

Impagidinium caspiense is most dominant in the Caspian and Aral Seas (Marret et al., 2004), although rare cysts of I. caspiense have been reported along the Black Sea coast and in the Marmara Sea (Mudie et al., 2017). Impagidinium cysts are usually found in open oceanic sediments from polar to equatorial latitudes covering a wide range of temperatures (Zonneveld et al., 2013). The modern sea-surface salinity range for $I$. caspiense is $11.7-17.5 \%$ (Mudie et al., 2017). The increase of relative abundance of $I$. caspiense at $0.10 \mathrm{~m}$ and lower, may indicate decrease in salinity or insufficient nutrient content of waters for Lingulodinium machaerophorum to exceed in numbers.

Cysts of Spiniferites cruciformis are only found in the Black Sea corridor and observed in coastal areas (Mudie et al., 2010). They are found mostly in brackish waters with high river discharge (Zonneveld et al., 2013). These dinocysts are found in a broad range of sea-surface temperatures, but they are more abundant in the warmest areas (Mudie et al., 2017). Most dinoflagellates are intolerable to the salinities higher than 35\%o, and their presence in the Lake Chokrak sediments is therefore associated with surface waters from the Sea of Azov. There are five intervals in the sequence where the dinocysts are present in relatively moderate numbers (Fig. 2). Thus, these intervals are related to periods when waters rise upwards, which led to increased availability of nutrients in the sea sur- 

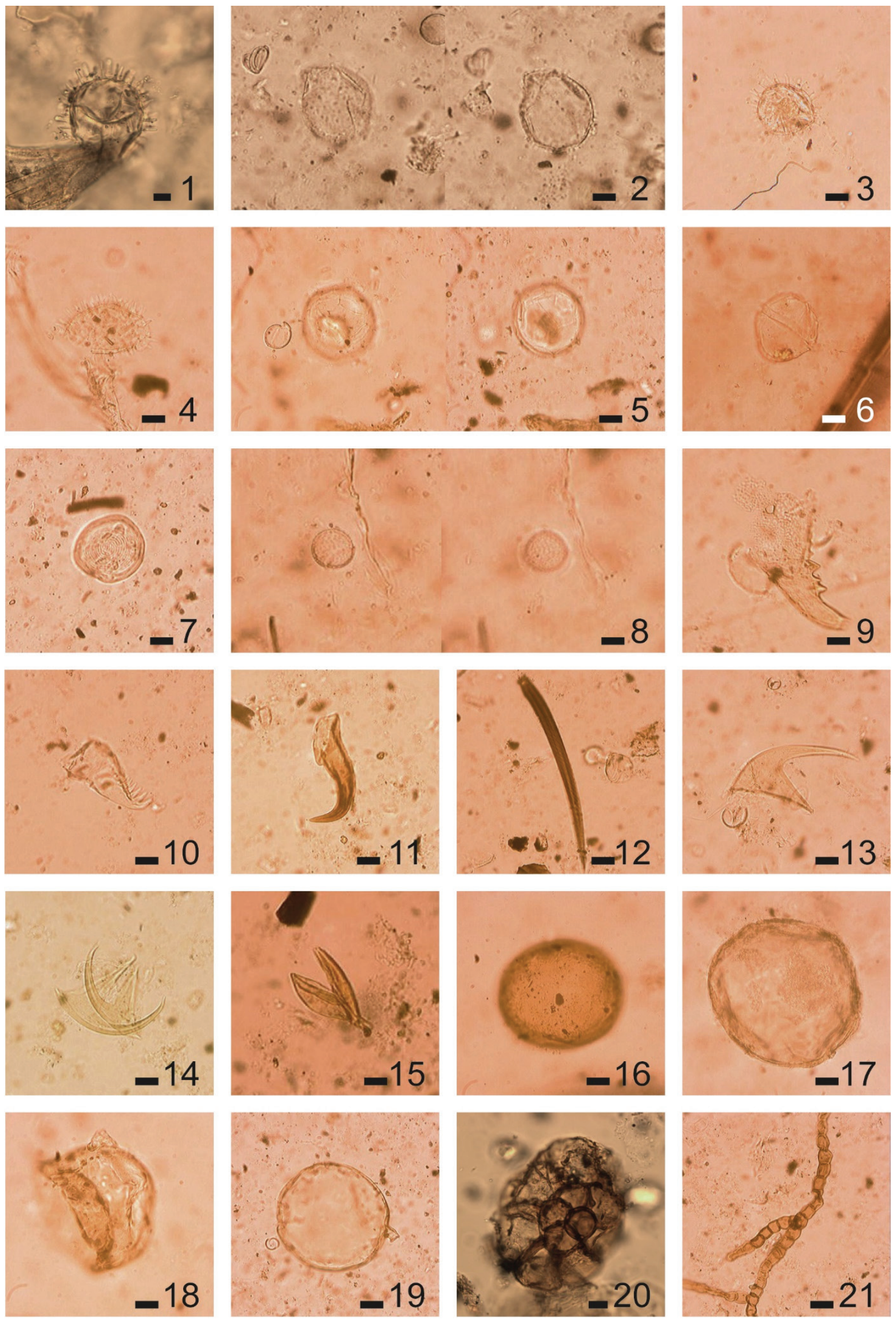

Fig. 3. Light microscope images of some non-pollen palynomorphs from the Lake Chokrak core. The scale bar is $10 \mu \mathrm{m}$. 1-4 - Lingulodinium machaerophorum; 5 - Gonyaulax baltica; 6 - Impagidinium caspiense; 7 - Pseudoschizaea circula; 8 - Sigmopollis sp.; 9-11 - mouth parts of small ostracods; 12-15 - exoskeletal parts of Arthropods; 16, 17 - crustacean eggs; 18 - an egg of Artemia salina; 19 - a spore of Glomus; 20 - a foraminiferal lining; 21 - a spore of Sporormiella sp. 
face waters and transport of dinocysts to the shore of the lake.

Acritarchs are palynomorphs with uncertain biological affinity, although it is assumed that they are a part of the life cycle of marine algae (Traverse, 1974). Batten (1996) states, that abundance of small, round acritarchs indicates nearshore, fine-grained marine sediments of variable salinity. Acritarch $C y$ matiosphaera globulosa belongs to the indicators of marine conditions, which was first shown by Pals et al. (1980) in the studies of peat and lake sediments in the Netherlands. Micrhystridium sp. is usually found in marine waters and is common in the Black Sea (Mudie et al., 2010). Wall (1965) reported that Micrhystridium favours nearshore environments that supports the idea that these specimens can be found at the sandbar between Lake Chokrak and Sea of Azov. Micrhystridium specimens have also been reported to be observed in saline Lakes Saki and Dzharylgach (Mudie et al., 2011). Acritarch Sigmopollis is considered to be a freshwater species and mostly found in mesotrophic water streams or calm water environments (van Geel et al., 1989), which suggests that its presence in Lake Chokrak is linked to transport from freshwater bodies.

From the various studies of fossil fungal spores, it is evident that the recorded spores in the majority of cases are of local occurrence. They were fossilised at, or near, the place where they had been produced, or the spores were deposited at only a short distance from the place where sporulation took place (van Geel., 2001). Spores of mycorrhizal fungus Glomus in the studied samples indicate soil erosion in the area around the lake or other soil disturbance (van Geel, 1989). Fungal spores, including Glomustype, are common in the saline Lake Saki, whereas in Lake Dzharylgach fungal spores are rare (Mudie et al., 2011). Spores of coprophilous fungi Delitschia, Podospora and Sporormiella are regularly reported in palynological samples from archaeological sites (Cugny et al., 2010) and indicate presence of human settlements or domestic livestock. In our case, they might indicate very recent agricultural usage of the lands around the lake.

Microforaminiferal linings indicate marine depositional environments, although they can be abundant in estuaries and lagoons of variable salinity. They have been widely used as marine indicators, whether occurring in abundance or as isolated specimens, and are common in clastic shelf sediments deposited in warm, shallow waters that are not greatly affected by terrestrial input (Batten, 1996). Therefore, microforaminiferal linings, which are present in the upper part of the sequence, are indicators of sea water incursions or sea-level changes in the Late Holocene. Ostracod mandibles and exoskeletal parts of Cladocera are also indicators of marine environments, especially shallow coastal basins. Linings of microforaminifera and ostracods are also reported in Lake Dzharylgach (Mudie et al., 2011). Crustacean Artemia salina is native to saline lakes, therefore its eggs are indicators of their autochthonous origin in the lake.

The sediments from both saline lakes Saki and Dzharylgach contain spores of colonial algae, $\mathrm{Pe}$ diastrum in particular, indicating freshwater input into the lakes, whereas in Lake Chokrak there is no evidence to support that.

Conclusion. The palynological study of the Lake Chokrak sediments revealed that sediment samples contain a relatively diverse assemblage of non-pollen palynomorphs, including dinoflagellate cysts, acritarchs, fungal spores, microforaminiferal linings and ostracod mandibles. The frequencies of dinocysts, algal and fungal spores are low, which can be explained by $\mathrm{NaOH}$ laboratory treatment of the samples, or by alkaline depositional environment of Lake Chokrak. The obtained data were interpreted in the light of known ecological affinities of individual species and their modern distribution. The majority of identified NPPs are indicators of marine conditions and are typically found in brackish/marine waters, therefore their presence in the studied samples indicates periods of increased wave activity and/or sea-level oscillations. We have been able to recognise five intervals when sea waters entered the lake basin. Human impact on the environment in the recent time has been traced by the presence of coprophilous fungal spores.

NPPs are useful for palaeoenvironmental reconstructions of coastal systems influenced by sea-level oscillations and climate changes. Ecological affinities of the studied palynomorphs can lead to general and detailed palynological conclusions about past depositional environments. Further study of NPPs can significantly contribute for interpretations based on pollen data and elaborate the Mid- and Late Holocene history of Lake Chokrak.

\section{References}

Batten, D.J., 1996. Chapter 26B. Palynofacies and palaeoenvironmental interpretation. In: Jansonius, J., McGregor, D.C. (Eds.) Palynology: principles and applications, Vol 3. American Association of Stratigraphic Palynologist Foundation, Dallas, 1065-1084.

Cugny, C., Mazier, F., Galop, D., 2010. Modern and fossil non-pollen palynomorphs from the Basque 
mountains (western Pyrenees, France): The use of coprophilous fungi to reconstruct pastoral activity. Vegetation History and Archaeobotany, 19(5), 391-408, DOI: 10.1007/s00334-010-0242-6.

Kelterbaum, D., Brückner, H., Dikarev, V., Gerhard, S., Pint, A., Porotov, A. and Zin'ko, V., 2012. Palaeogeographic Changes at Lake Chokrak on the Kerch Peninsula, Ukraine, during the Mid and Late Holocene. Geoarchaeology, 27, 206-219, doi:10.1002/gea.21408.

Kurnakov, N.S., Kuznetsov, V.G., Dzens-Litovskiy, A.I., Ravich, M.I., 1936. Solyanye ozera Kryma [Salt lakes of the Crimea]. Academy of Sciences, Moscow-Leningrad (In Russian).

Marret, F., Leroy, S., Chalie, F., Gasse, F., 2004. New organic-walled dinoflagellate cysts from recent sediments of Central Asian seas. Review of Palaeobotany and Palynology, 129, 1-20, https://doi. org/10.1016/i.revpalbo.2003.10.002.

Marret, F., Mudie, P., Aksu, A., Hiscott, R., 2009. A Holocene dinocyst record of a two-step transformation of the Neoeuxinian brackish water lake into the Black Sea. Quaternary International, 197, 72-86, https://doi.org/10.1016/j.quaint.2007.01.010.

Mudie, P.J., Leroy, S.A.G., Marret, F., Gerasimenko, N., Kholeif, S.E.A., Sapelko, T., Filipova-Marinova, M., 2011. Nonpollen palynomorphs: Indicators of salinity and environmental change in the Caspian-Black Sea-Mediterranean corridor. In: Buynevich, I., Yanko-Hombach, V., Gilbert, A.S., and Martin, R.E., eds., Geology and Geoarchaeology of the Black Sea Region: Beyond the Flood Hypothesis: Geological Society of America Special Paper 473, 89-115, doi:10.1130/2011.2473(07).

Mudie, P.J., Marret, F., Mertens, K.N., Shumilovskikh, L., Leroy, S.A.G., 2017. Atlas of modern dinoflagellate cyst distributions in the Black Sea Corridor: from Aegean to Aral Seas, including Marmara, Black, Azov and Caspian Seas. Marine Micropaleontology, 134, 1-152, https://doi.org/10.1016/j. marmicro.2017.05.004.

Mudie, P.J., Marret, F., Rochon, A., Aksu, A.E., 2010. Nonpollen palynomorphs in the Black Sea corridor. Vegetation History and Archaeobotany, 19, 531544, https://doi.org/10.1007/s00334-010-0268-9.

Mudie, P.J., Rochon, A., Aksu, A.E., Gillespie, H., 2002. Dinoflagellate cysts, freshwater algae and fungal spores as salinity indicators in Late Quaternary cores from Marmara and Black seas. Marine geology, 190, 203-231, https://doi.org/10.1016/S00253227(02)00348-1.

Pals, J.P., van Geel, B., Delfos, A., 1980. Palaeocological studies in the Klokkeweel bog near Hoogkarspel (prov. of Noord Holland). Review of Palaeobotany and Palynology, 30, 371-418.

Shumilovskikh, L.S., Marret, F., Fleitmann, D., Arz, H.W., Nowaczyk, N., Behling, H., 2013. Eemian and Holocene sea-surface conditions in the southern Black Sea: Organic-walled dinoflagellate cyst record from core 22-GC3. Marine Micropaleontology, 101, 146-160, https://doi.org/10.1016/j.marmicro.2013.02.001.

Traverse, A., 1974. Palynological investigation of two Black Sea cores. In: Degens, E.T., Ross, D.A. (Eds.) The Black Sea: geology, chemistry, and biology. American Association of Petroleum Geologists, Memoir 20, Tulsa, 381-388.

Traverse, A., 1978. Palynological analysis of DSDP Leg 42B (1975) cores from the Black Sea. In: Ross et al. (Eds.) Initial reports of the Deep Sea Drilling Program, Vol. 42 (part 2). U.S. Government Printing Office, Washington, DC, 993-1015.

Van Geel, B., Coope, G.R., van der Hammen, T., 1989. Palaeoecology and stratigraphy of the Late-glacial type section at Usselo (The Netherlands). Review of Palaeobotany and Palynology, 60, 25-129.

Van Geen, B., 2001. Non-pollen palynomorphs. In: Smol, J.P., Birks, H.J.B., Last, W.M. (Eds.) Tracking environmental change using lake sediments, Vol. 3: Terrestrial, algal and silicious indicators. Kluwer, Dordrecht, https://doi.org/10.1007/0-306-476681_6.

Wall, D., 1965. Modern histrochospheres and dinoflagellate cysts from the Woods Hole region. Grana Palynologica, 6 (2), 297-314.

Wall, D., Dale, B., Harada, K., 1973. Descriptions of New Fossil Dinoflagellates from the Late Quaternary of the Black Sea. Micropaleontology, 19, 18-31.

Wall., D., Dale, B., 1974. Dinoflagellates in Late Quaternary deep-water sediments of Black Sea. In: Degens, E.T., Ross, D.A. (Eds.) The Black Sea: geology, chemistry, and biology. American Association of Petroleum Geologists, Memoir 20, Tulsa, 364380 .

Zonneveld, K.A.F., Marret, F., Versteegh, G.J.M., Bogus, K., Bonnet, S., Bouimetarhan, I., Crouch, E., de Vernal, A., Elshanawany, R., Edwards, L., et al., 2013. Atlas of modern dinoflagellate cyst distribution based on 2405 data points. Review of Palaeobotany and Palynology, 191, 1-197, https://doi. org/10.1016/j.revpalbo.2012.08.003.

Zonneveld, K.A.F., Pospelova, V., 2015.Adetermination key for modern dinoflagellate cysts. Palynology, 39:3, 387-409, DOI: 10.1080/01916122.2014.990115. 